\title{
ANALISIS MANAJEMEN RISIKO DALAM PEMBIAYAAN MURABAHAH PADA PT. BPRS BAITURRAHMAN DI ACEH BESAR
}

\author{
Mukhlis \\ Direktur PT BPRS Adeco Langsa Aceh \\ mukhlis8181@gmail.com
}

\begin{abstract}
This study aims to determine the Murabahah Financing Risk Management Procedure, implementation of Murabahah Financing Risk Management, Impact of the Implementation of Murabahah Financing Risk Management and How to Implement Murabahah Financing Risk Management from the Perspective of Islamic Economic Law. This study used a descriptive qualitative design. Research data obtained from surveys, interviews and documentation studies. The data analysis used descriptive techniques, the implementation of which was carried out in three stages, namely the data reduction stage, the display stage (data grouping), and the verification stage. The results showed that the Murabahah Financing Risk Management Procedure implemented by PT. BPRS Baiturrahman is very concrete and detailed and serves as a reference in the Murabahah financing process. Murabahah Risk Management Implementation at PT. BPRS Baiturrahman uses the principle of prudence with a factor of $5 \mathrm{C}$, namely Character, Capacity, Capital, Colleteral and Condition. The implementation of Murabahah Financing Risk Management did not run optimally, this can be seen from the increase in the NPF of murabahah financing. Implementation of Financing Risk Management based on the Perspective of Islamic Economic Law, in general the implementation of risk management for murabahahah financing at PT. BPRS Baiturrahman pays close attention to provisions related to implementation in accordance with applicable sharia principles including Fatwa DSN-MUI No.04 / DSN-MUI / IV / 2000 in its implementation being supervised by the Dewan Pengawas Syariah
\end{abstract}

Keywords: Risk management, Murabahah financing, PT. BPRS Baiturrahman

\begin{abstract}
Abstrak
Penelitian ini bertujuan untuk mengetahui Prosedur Manajemen Risiko Pembiayaan Murabahah, implementasi Manajemen Risiko Pembiayaan
\end{abstract}


Murabahah, Dampak Implementasi Manajemen Risiko Pembiayaan Murabahah dan Bagaimana Pelaksanaan Manajemen Risiko Pembiayaan Murabahah dalam Perspektif Hukum Ekonomi Islam. penelitian ini menggunakan desain kualitatif deskriptif. Data peneltian diperoleh dari survey, wawancara dan studi dokumentasi. Analisis data menggunakan teknik deskriptif yang penerapannya dilakukan dalam tiga alur tahapan, yaitu tahap reduksi data, tahap display (mengelompokkan data), dan tahap verifikasi. Hasil penelitian menunjukkan bahwa Prosedur Manajemen Risiko Pembiayaan Murabahah yang diterapkan oleh PT. BPRS Baiturrahman sangat kongkret dan detail serta menjadi acuan dalam proses pembiayaan Murabahah. Implementasi Manajemen Risiko Murabahah pada PT. BPRS Baiturrahman menggunakan prinsip kehati-hatian dengan faktor $5 \mathrm{C}$, yaitu Character, Capacity, Capital, Colleteral dan Condition. Implementasi Manajemen Risiko Pembiayaan Murabahah tidak berjalan secara maksimal, hal tersebut terlihat dari peningkatan NPF pembiayaan murabahah. Pelaksanaan Manajemen Risiko Pembiayaan berdasarkan Perspektif Hukum Ekonomi Islam, secara umum pelaksanaan manajemen risiko pembiayaan murabahahah pada PT. BPRS Baiturrahman sangat memperhatikan ketentuan terkait pelaksanan sesuai dengan prinsip-prinsip syariah yang berlaku diantaranya Fatwa DSNMUI No.04/DSN-MUI/IV/2000 dalam pelaksanaan nya diawasi oleh Dewan Pengawas Syariah.

Kata kunci: Manajemen risiko, pembiayaan Murabahah, PT. BPRS Baiturrahman.

\section{Pendahuluan}

Lembaga keuangan adalah sejenis lembaga perantara yang fungsi dan perannya menghimpun dana dari pihak yang memiliki dana terlalu banyak dan mengarahkan dananya kepada mereka yang kekurangan atau membutuhkan dana, untuk mencapai kehidupan masyarakat yang adil, dan sejahtera (Kasmir, 2004: 33). Salah satu lembaga keuangan yang sangat dibutuhkan masyarakat adalah perbankan. Bank adalah sebagian besar perusahaan yang dilindungi/tertuang dalam berbagai peraturan perundang-undangan dan rentan terhadap permasalahan yang berkaitan dengan perekonomian manusia. Jika suatu saat terjadi suatu masalah, setiap kegiatan akan berdampak luas, sehingga perlu mengutamakan manajemen risiko khusus perbankan. Perkembangan perbankan syariah yang berkelanjutan juga akan berdampak pada peningkatan risiko pengelolaannya (Veithzal \& Ismal, 2013: 25). Perkembangan Perbankan syariah Indonesia yang mencakup atas Bank Pembiayaan Rakyat syariah (BPRS), Bank Umum Syariah (BUS) dan Unit Usaha Syariah (UUS) terus menunjukkan pertumbuhan positif. 
Gambar 1.1

Perkembangan Asset Perbankan Syariah

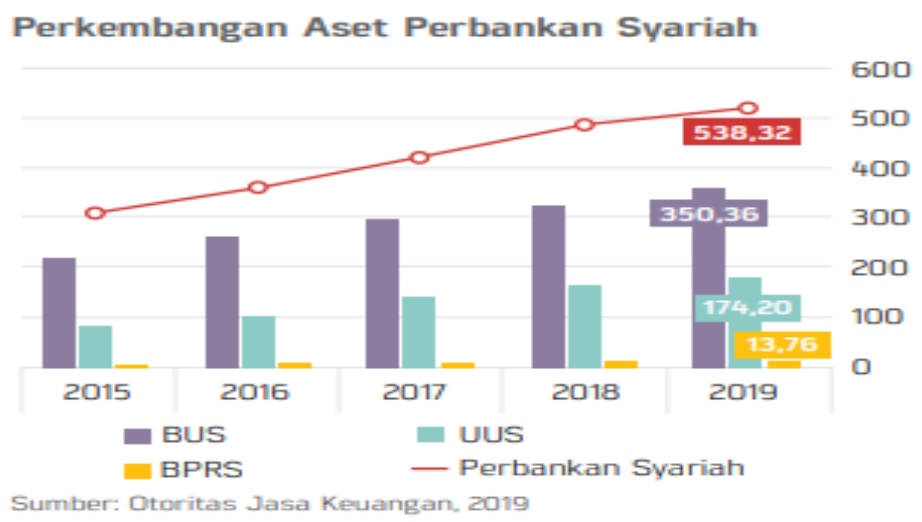

Perkembangan bisnis perbankan syariah sangat pesat, sehingga perbankan syariah memiliki peluang dan potensi yang besar untuk memberikan pembiayaan bagi perekonomian. Dalam perbankan syariah terdapat tiga jenis pembiayaan sebagai produk utama yaitu: pembiayaan Mudharabah, Pembiayaan Murabahah dan Pembiayaan Musyarakah (Dedi Putra dan Nur Istiqomah, 2020). Namun, jenis pembiayaan yang paling sering digunakan adalah produk pembiayaan Murabahah. Pembiayaan Murabahah menjadi akad yang lebih dominan digunakan karena mudah diaplikasikan dan mempunyai risiko yang relatif kecil. Namun, produk Murabahah tidak sepenuhnya aman dan bebas risiko karena risiko dapat muncul disebabkan besarnya nominal pembiayaan, jangka waktu dan lama pembiayaan serta faktor-faktor lain yang tercantum dalam pembiayaan seperti masalah jaminan dan karakter nasabah (Ascarya, 2006: 76).

Kebijakan manajemen risiko mempunyai tujuan untuk mengidentifikasi, mengukur, memantau dan mengendalikan proses kegiatan usaha perbankan secara terarah, komprehensif serta berkelanjutan dengan tingkat risiko yang wajar. Oleh karena itu, manajemen risiko dapat digunakan sebagai filter atau sistem peringatan dini (early warning system) bagi aktivitas perbankan (Karim, 2005: 225). Untuk dapat menerapkan proses manajemen risiko, bank harus secara akurat mengidentifikasi dan memahami semua risiko yang ada (risiko inheren) atau risiko yang mungkin timbul dari operasional bank baru termasuk risiko yang berasal dari perusahaan yang terkait dengan cabang lain pada tahap awal risiko. Salah satu Bank Syariah yang telah membentuk dan menjalankan pejabat eksekutif manajemen risiko adalah PT. Bank Pembiayaan Rakyat Syariah Baiturrahman.

PT. Bank Pembiayaan Rakyat Syariah Baiturrahman berada di J1. Mata Ie, Lam Bheu Kecamatan Darul Imarah Kabupaten Aceh Besar. PT. Bank Pembiayaan Rakyat Syariah Baiturrahman sebagai lembaga perbankan yang menawarkan berbagai produk-produk perbankan, baik produk 
pendanaan maupun pembiayaan. Namun, produk yang paling banyak dipilih oleh masyarakat adalah produk pembiayaan dan produk pembiayaan yang paling diminati yaitu pembiayaan Murabahah. Hal ini terlihat dari kondisi pembiayaan Murabahah di tahun 2015 yang terus meningkat setiap tahunnya sebesar 15,3 milyar, tahun 2016 sebesar 20,4 milyar, tahun 2017 sebesar 22,8 milyar, tahun 2018 sebesar 25 milyar dan pada tahun 2019 sebesar 25,7 milyar. Tentu saja, semakin banyak pembiayaan Murabahah yang disalurkan, maka akan semakin besar pula risiko yang akan dihadapi oleh PT. BPRS Baiturrahman. Oleh karena itu, PT. BPRS telah menerapkan prinsip-prinsip manajemen risiko.

PT. BPRS Baiturrahman telah membentuk pejabat eksekutif dan menerapkan manajemen risiko yang sesuai dengan peraturan pembiayaan murabahah, yaitu berdasarkan fatwa Dewan Syariah Nasional Majelis Ulama indonesia No.04/DSN-MUI/IV/2000 terkait Murabahah sebagai dasar kebijakan terhadap pembiayaan Murabahah sejak tahun 2019 lalu. Seharusnya dengan adanya manajemen risiko yang baik dan sesuai dengan peraturan yang berlaku, maka PT. BPRS Baiturrahman mampu meminimalisir pembiayaan Murabahah yang bermasalah. Namun, pada kenyataannya tingkat NPF PT. BPRS Baiturrahman meningkat dari tahun 2018, yaitu NPF tahun 2018 sebesar 9,97\% meningkat menjadi 11,00\% di tahun 2019.

Berdasarkan permasalahan di atas, maka penulis akan melakukan penelitian lebih mendalam terkait manajemen risiko pembiayaan Murabahah di PT. Bank Pembiayaan Rakyat Syariah (BPRS) Baiturrahman. Oleh karena itu penulis mengambil judul "Analisis Manajemen Risiko dalam Pembiayaan Murabahah pada PT. BPRS Baiturrahman di Aceh besar".

\section{Metode Penelitian}

Jenis penelitian yang digunakan dalam penelitian ini adalah penelitian kualitatif deskriptif, yaitu data yang terkumpul berupa kata-kata dan gambar, bukan angka (Sudarwan Danim, 2002: 51). Metode penelitian kualitatif digunakan untuk meneliti pada kondisi obyek yang alamiah, dimana peneliti adalah sebagai instrumen kunci. Sedangkan hasil penelitian kualitatif lebih menekankan makna dari pada generalisasi (Sugiyono, 2007: 15). Penelitian deskriptif merupakan suatu bentuk penelitian yang bertujuan mendeskripsikan fenomena yang ada seperti fenomena alam dan ergonomic (rekayasa manusia). Penelitian deskriptif bertujuan untuk mendeskripsikan secara sistematis, faktual dan akurat mengenai fakta yang terjadi, ciri dan fenomena yang diteliti (Nazir, 2002: 54). Dari data-data yang telah dikumpulkan, diolah, dianalisis dan disajikan, data yang didasarkan kepada pendekatan fenomena yang terjadi dalam praktek pelaksanaan manajemen risiko pembiayaan Murabahah pada PT. Bank Pembiayaan Rakyat Syariah Baiturrahman.

Sumber data yang dimaksud dalam penelitian ini adalah subjek dari mana data tersebut dapat diperoleh, saat menggunakan wawancara untuk 
mengumpulkan data, sumber data disebut informan, yaitu orang yang menjawab atau menjawab pertanyaan secara tertulis dan lisan. Dalam observasi, sumber datanya berupa objek, Gerakan atau proses tertentu. Saat menggunakan dokumen atau record sumber datanya. Subjek dalam penelitian ini adalah PT. Bank Pembiayaan Rakyat Syariah Baiturrahman yang berada di J1. Mata Ie, Lam Bheu Kecamatan Darul Imarah Kabupaten Aceh Besar.

Metode pengumpulan data yang digunakan dalam penelitian ini adalah teknik survei, wawancara, studi dokumentasi, dan studi pustaka. Teknik analisis data, dimana pada dasarnya analisis data merupakan penguraian data melalui tahapan kategorisasi dan klasifikasi, perbandingan dan pencarian penjelasan. Analisis data dalam penelitian ini adalah data yang muncul berupa kata-kata dan bukan merupakan rangkaian angka serta prosedur analisis data terbagi tiga, yaitu: Pengurangan data (reduksi),Penyajian data (display) dan Penarikan kesimpulan (conclusion).

\section{Bank Pembiayaan Rakyat Syariah}

Bank Pembiayaan Rakyat Syariah (BPRS) adalah bank syariah yang tidak memberikan layanan arus pembayaran dalam kegiatannya (Pasal 1 UU Perbankan Syariah). Semua peraturan perundang-undangan yang terkait dengan Bank Perkreditan Rakyat Syariah yang mengacu pada BPRS Wajib dibaca bersama kata syariah Bank Perkreditan Rakyat (UU. No. 21 Tahun 2008). Bank Pembiayaan Rakyat Syariah (BPRS) merupakan bank syariah yang tidak memberikan layanan pembayaran dalam kegiatannya. Bank Perkreditan Rakyat Syariah (BPRS) tidak dapat dikonversi menjadi Bank Perkreditan Rakyat (BPR). Bank Perkreditan Rakyat Syariah tidak diperbolehkan membuka cabang, kantor perwakilan dan jenis kantor lainnya di luar negeri.

\section{Manajemen Risiko}

Risiko adalah peluang dimana hasil yang sesungguhnya bisa berbeda dengan hasil yang sesungguhnya bisa berbeda dengan hasil yang diharapkan atau kemungkinan nilai yang hilang atau diperoleh yang dapat diukur, risiko berbeda dengan ketidakpastian yang tidak dapat diukur. Risiko didefinikan sebagi bentuk-bentuk peristiwa yang mempunyai pengaruh terhadap kemampuan seseorang atau sebuah institusi untuk mencapai tujuan (Tampubolon, 2014: 17). Risiko dalam konteks perbankan merupakan suatu kejadian potensia, baik yang dapat diperkirakan (anticipated) maupun yang tidaka dapat diperkirakan (un anticipated) yang berdampak negatif terhadap pendapatan dan permodalan bank. Risiko tersebut tidak dapat dihindari tetapi dapat di kelola dan dikendalikan (Karim, 2005: 66).

Manajemen adalah sebagai usaha perencanaan, koordinasi, serta pengaturan sumber daya yang ada untuk mencapai tujuan secara efektif dan efisien (Suparmin, 2019). Sedangkan manajemen risiko adalan suatu bidang ilmu yng membahas tentang bagaimana suatu organisasi menerapkan ukuran dalam memetakan berbagai permasalahan yang ada dengan menempatkan berbagai pendekatan manajemen secara komprehensif dan sistematis 
(Muhammad, 2002: 1). Manajemen risiko adalah penerapan fungsi-fungsi manajemen dalam menanggulangi risiko yang dihadapi oleh organisasi jadi, manajemen risiko organisasi adalah suatu sistem yang dihadapi organisasi secara komperhensif untuk tujuan meningkatkan nilai perusahaan. Tujuan utama dari manajemen risikoadalah untuk memastikan bahwa seluruh kebijakan risiko dan dan bisnis bisa diimplementasikan secara konsisten.

\section{Corporate Governance dalam Proses Manajemen Risiko}

Corporate governance atau tata kelola perusahaan adalah sistem yang dipergunakan dalam mengarahkan dan mengendalikan kegiatan bisnis perusahaan (Bhagat \& Bolton, 2019). Corporate governance ini juga mengandung pengertian mengenai pengaturan atas pembagian tugas dan tanggung jawab di antara para pihak atau para "key players" yang berpartisipasi dan memiliki kepentingan yang berbeda-beda dalam perusahaan (Kovermann \& Velte, 2019). Para pihak yang berkepentingan atas pengarahan dan pengendalian perusahaan itu meliputi: dewan direksi, para manager, para pemegang saham, dan stakeholders lainnya (Jiang \& Kim, 2020). Oleh karena itu, corporate governance juga dapat didefinisikan sebagai seperangkat hubungan antara dewan komisaris, dewan direksi atau board of executive directors, stakeholders, dan pemegang saham suatu perusahaan.

\section{Pembiayaan Murabahah}

Dalam UU Perbankan 10 Oktober 1998, Pasal 1 ayat 12, pembiayaan mengacu pada penyediaan dana atau utang yang setara berdasarkan kesepakatan atau peluang antara bank dengan pihak lain dan perjanjian atau peluang tersebut mengharuskan pihak yang didanai untuk kembali setelah jangka waktu tertentu. Pembayaran atau klaim sebagai imbalan bagi hasil (Kasmir, 2004: 92). Murabahah adalah akad penyediaan barang berdasarkan sistem jual beli, dimana bank membelikan kebutuhan nasabah (barang) dan menjual kembali kepada nasabah ditambah dengan keuntungan yang disepakati bersama (Muhammad, 2014: 311). Harga penuh barang dibayar oleh pembeli (pelanggan) dengan mencicil. Kepemilikan aset ini dialihkan kepada pelanggan (pembeli) secara proporsional dengan pembayaran angsuran. Oleh karena itu, barang yang dibeli akan dijadikan jaminan hingga semua biaya lunas. Hal ini juga memungkinkan bank untuk meminta jaminan tambahan dari nasabah terkait.

\section{Risiko Pembiayaan Murabahah}

Pembiayaan murabahah merupakan pembiayaan yang dicirikan dengan adanya penyerahan barang di awal akad dan pembayarannya kemudian, baik dalam bentuk angsuran atau maupun dalam bentuk lumpsum (sekaligus). Dengan demikian, pembelian pembiayaan murabahah dengan jangka waktu panjang menimbulkan risiko tidak bersaingnya bagi hasil kepada dana pihak ketiga. Lembaga Keuangan Syari'ah dapat menetapkan mempertimbangkan hal-hal sebagai berikut: 
1. Tingkat (margin) keuntungan saat ini dan prediksi perubahannya dimasa mendatang yang berlaku di pasar perbankan syariah.

2. Suku bunga kredit saat ini dan prediksi perubahannya di masa mendatang yang berlaku dipasar perbankan konversional.

3. Ekspektasi bagi hasil kepada dana pihak bank ketiga yang konpentitif di pasar perbankan syariah.

\section{Prosedur Manajemen Risiko pada PT. BPRS Baiturrahman Banda Aceh}

Prosedur pembiayaan PT BPRS Baiturrahman tertuang dalam Standar operasional prosedur (SOP) tentang pembiayaan dengan Surat Keputusan Direksi pada tahun 2019 yang mengatur semua aktifitas operasional pembiayaan. SOP tersebut setiap tahun dilakukan audit oleh OJK dan dianggap telah memenuhi ketentuan yang terkait Peraturan Otoritas Jasa Keuangan. Prosedur pembiayaan Murabahah dalam SOP pembiayaan dimulai dari Tahapan awal dalam mengajukan pembiayaan pada BPRS Baiturrahman adalah menyiapkan dokumen-dokumen berupa : pengisian formulir permohonan pembiayaan, fotokopi KTP, fotokopi Kartu Keluarga, fotokopi dokumen agunan dan lain-lain. Setelah seluruh data kelengkapan terkonfirmasi lengkap pihak bank akan melakukan wawancara terhadap calon nasabah yang bersangkutan dengan melakukan survei ke rumah serta lokasi yang menjadi agunan pembiayaan dengan tujuan untuk mengetahui lebih mendalam profil dari calon nasabah. Pengecekan ini juga untuk melihat kesesuaian data yang tertulis dengan data yang ada dilapangan. Berdasarkan hasil wawancara yang dilakukan pada ibu Farhatul Mahya yang merupakan Customer service menyatakan: "Setelah nasabah yang bersangkutan memenuhi semua kelengkapan yang bersifat administratif, maka selanjutnya pihak bank, disini yang biasanya ditunjuk untuk memproses pembiayaan nasabah adalah AO (Account Officer). Petugas AO ini akan melakukan tahapan riwayat pembiayaan nasabah dengan Idebt Slik melalui web OJK, kemudian menganalisis kemampuan nasabah baru kemudian keputusan pembiayaan yang diajukan nasabah diterima atau ditolak."

Berdasarkan penuturan pegawai bank tersebut, dapat diuraikan bahwa setelah seluruh proses kelengkapan data nasabah diperoleh dengan benar dan tervalidasi maka langka selanjutnya yang dilakukan oleh pihak bank adalah melakukan pengecekan pada Bank Indonesia (BI Checking) dengan tujuan memperoleh informasi secara menyeluruh apakah calon nasabah tersebut memiliki pinjaman terhadap lembaga keuangan lain, baik dibank ataupun lembaga keuangan non bank lainnya serta untuk mengetahui apakah nasabah tersebut masuk dalam daftar hitam (blacklist) kredit macet atau tidak. selanjutnya pihak bank akan melakukan analisis kemampuan nasabah atas data yang telah dikumpulkan tentang kemampuan serta kesanggupan nasabah untuk melunasi kewajibannya secara tepat waktu sesuai dengan perjanjian nantinya. 
Skema Proses Pembiayaan Murabahah PT. BPRS Baiturrahman

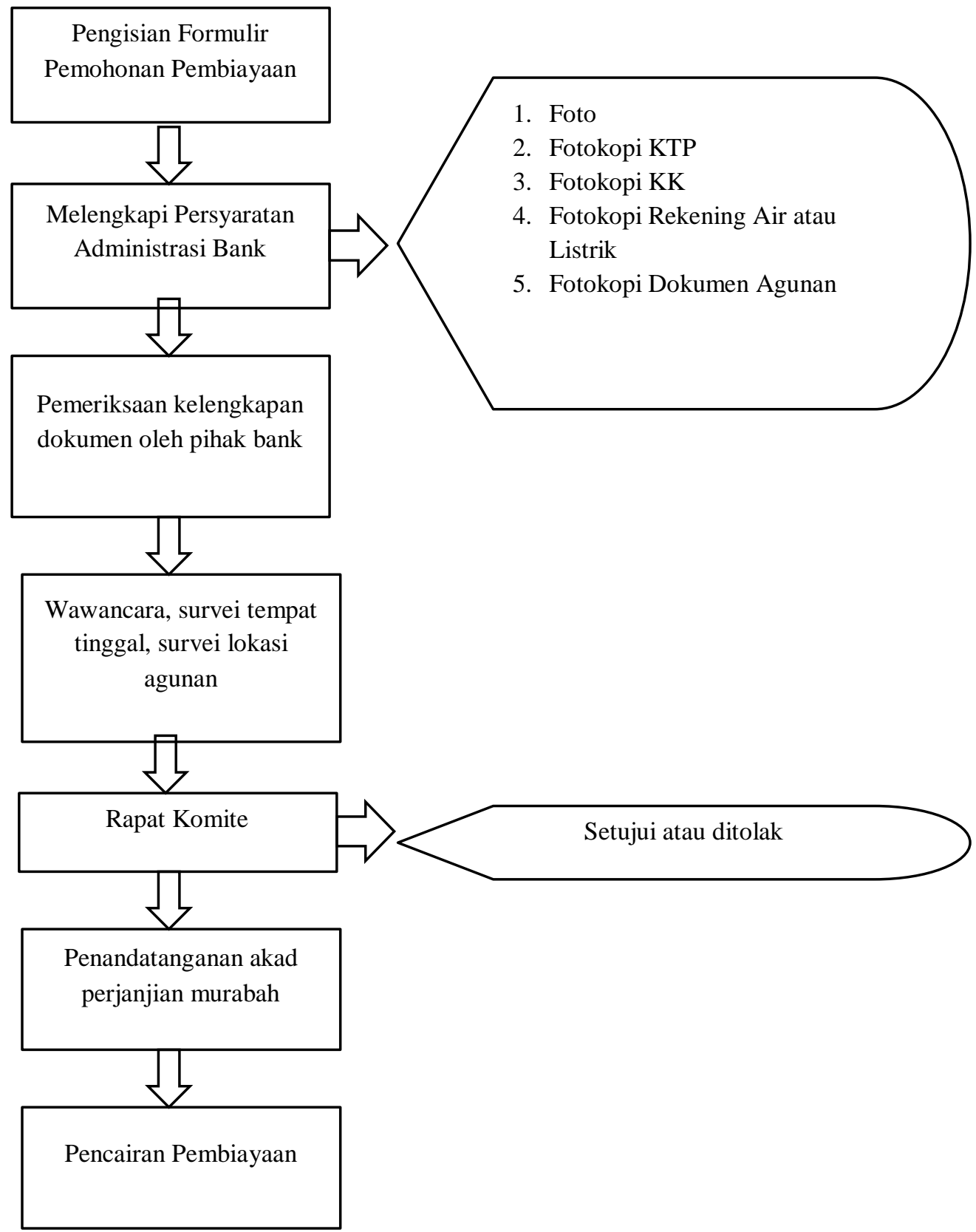

\section{Implementasi Manajemen Risiko Pembiayaan Murabahah}

Pembiayaan dengan dasar akad Murabahah merupakan transaksi jual beli suatu barang sebesar harga perolehan ditambah dengan margin (keuntungan), dimana pihak penjual wajib menginformasikan kepada pembeli harga pokok barang tersebut serta jumlah margin yang ditambahkan sebagai keuntungan dari penjual. Akad Murabahah didalam bank syariah digunakan para nasabah untuk memperoleh barang yang menjadi kebutuhan mereka, 
dimana pihak bank memposisikan diri sebagai penjual dan nasabah sebagai pembelinya. Dalam pemberian pembiayaan kepada calon nasabah, bank tentu menerapkan Standard Operating Prosedure (SOP) yang merupakan pedoman bagi para account officer (AO) dalam mengambil keputusan. Dengan banyaknya kemungkinan resiko yang akan timbul bank tentu harus menerapkan prinsip kehati-hatian dalam menyalurkan pembiayaan. Sebagaimana hasil wawancara yang dilakukan pada Komite Manajemen Risiko PT. BPRS Baiturrahman, yaitu Bpk Ahmad Syihan Ali, beliau mengatakan:

"Ada banyak sekali risiko yang akan muncul saat pembiayaan diberikan kepada nasabah, untuk menghindari hal-hal yang nantinya malah merugikan pihak bank, oleh karena itu kami selaku pihak bank menerapkan prinsip 5C dalam memberikan pembiayaan pada nasabah, yang meliputi: penilaian karakter, penilaian terhadap kemampuan nasabah, penilaian terhadap aset yang nasabah miliki, penilaian terhadap agunan serta melihat situasi perkembangan ekonomi untuk masa sekarang hingga jangka panjang untuk masa yang akan datang. Semua hal ini tentu memiliki tujuan menghindari risiko kredit macet."

\section{Dampak Implementasi Manajemen Risiko Pembiayaan Murabahah}

Manajemen pada suatu bank merupakan suatu kegiatan yang sangat penting, hal ini bertujuan agar dapat tercapainya tujuan perusahaan secara optimal. Meskipun demikian risiko-risiko yang timbul atas penyaluran pembiayaan tidak dapat dihindari untuk itu manajemen risiko harus benarbenar diterapkan dalam penyaluran pembiayaan. Untuk menilai risiko kredit atau pembiayaan pada bank syariah diukur menggunakan rasio Non Performing Finance (NPF) yaitu membandingkan pembiayaan bermasalah dengan total keseluruhan pembiayaan. Berikut tabel kriteria penetapan peringkat profil risiko NPF :

Tabel 1.1.

Kriteria Penetapan Peringkat Profil Risiko NPF

\begin{tabular}{|c|c|c|}
\hline Peringkat & Keterangan & Kriteria \\
\hline 1 & Sangat Sehat & NPF $<2 \%$ \\
\hline 2 & Sehat & $5 \% \leq \mathrm{NPF}<8 \%$ \\
\hline 3 & Cukup Sehat & $8 \% \leq \mathrm{NPF}<12 \%$ \\
\hline 4 & Kurang Sehat & $\mathrm{NPF} \geq 12 \%$ \\
\hline 5 & Tidak Sehat & $2 \%$ \\
\hline
\end{tabular}

Sumber : Surat Edaran Bank Indonesia No. 6/23/DPNP Tahun 2004

Berdasarkan laporan keuangan pada PT. BPRS Baiturrahman, tingkat NPF tahun 2018 yaitu sebesar 9,97\% dan pada tahun 2019 mengalami peningkatan sebesar $1.03 \%$ dari tahun 2018 menjadi 11\%. Jika ditinjau berdasarkan peringkat profil risiko NPF yang mengacu pada Surat Edaran 
BI, maka NPF pada PT. BPRS Baiturrahman dinilai kurang sehat. Efektivitas pengelolaan risiko dalam sebuah bank itu tercermin dari rasio kredit bermasalah (non performing finance), setiap lembaga keuangan bank harus mempunyai cara untuk menangani potensi-potensi masalah yang sesuai dan tepat guna. Pengelolaan manajemen risiko yang baik akan berdampak positif pada kinerja bank. Sebagaimana hasil wawancara yang dilakukan pada Direktur Utama PT. BPRS Baiturrahman terkait manajemen risiko, Bapak Rahmad Hardiyanto : "Parameter yang dipergunakan dalam melakukan penilaian terhadap pengendalian risiko kredit utamanya meliputi pengawasan aktif Dewan Komisaris dan Direksi yang terdiri dari sejauh mana Dewan Komisaris dan Direksi mampu memahami dan mengelola risiko kredit dengan menerapkan prosedur serta regulasi untuk mengendalikan risiko kredit, serta menempatkan pegawai yang kompeten untuk merespon setiap perubahan pada risiko kredit."

\section{Pelaksanaan Manajemen Risiko Pembiayaan Dalam Perspektif Hukum Ekonomi Syariah}

Pelaksanaan manajemen risiko pembiayaan yang sesuai dengan hukum ekonomi syariah merupakan suatu keharusan dalam praktek operasional lembaga keuangan bank, hal tersebut sesuai dengan peraturan Otoritas Jasa Keuangan tentang Bank Pembiayaan Rakyat Syariah tentang kewajiban pelaksanaan prinsip-prinsip syariah dalam pelaksanaan operasionalnya yang tentunya aturannya mengacu pada fatwa-fatwa Dewan Syariah Nasional Majelis ulama Indonesia dan dalam pelaksanaannya diawasi oleh Dewan Pengawas Syariah. Sebagaimana hasil wawancara yang dilakukan dengan Bapak Rahmad Hardiyanto selaku Direktur Utama PT. BPR Syariah Adeco : "Pelaksanaan manajemen risiko pembiayaan pada PT. BPRS Baiturrahman sangat memperhatikan proses proses dalam aktifitas perusahaan dan harus sesuai dengan prinsip-prinsip syariah dengan mengacu kepada peraturan Otoritas Jasa Keuangan, peraturan perusahaan yang terkait dan dalam praktek produk perbankan mengacu pada FatwaFatwa DSN-MUI, serta pengawasan aktif dari Dewan Pengawas Syariah"

Berdasarkan hasil wawancara diatas dapat disimpulkan bahwa Pada praktiknya terdapat upaya yang serius dari manajemen PT. BPRS Baiturrahman dalam menjalankan kegiatan usahanya sesuai dengan prinsip-prinsip syariah dan dalam aktifitas nya diawasi secara aktif oleh Dewan Pengawas Syariah. 


\section{Kesimpulan}

Berdasarkan hasil analisis penelitian dan pembahasan yang telah diuraikan, maka dapat disimpulkan beberapa hal antara lain : Pertama, Prosedur Manajemen Risiko Pembiayaan Murabahah yang selalu diterapkan oleh PT. BPRS Baiturrahman sangat kongkret dan detail dengan pemeriksaan kelengkapan data dan dokumen-dokumen yang terkait dengan calon nasabah. Tidak hanya itu, implementasi Manajemen Risiko Pembiayaan Murabahah selalu menggunakan prinsip kehati-hatian dengan faktor 5 C, yaitu Character, Capacity, Capital, Colleteral dan Condition. Implementasi faktor Character dilakukan dengan prosedur wawancara kepada calon nasabahuntuk menilai personality dan kepribadian calon nasabah. Kedua, Implementasi Manajemen Risiko Pembiayaan Murabahah pada PT. BPRS Baiturrahman harusnya mampu menurunkan tingkat nasabah bermasalah baik nominal maupun rasio. Namun pada kenyataannya tingkat nasabah bermasalah pada tahun 2019 lebih besar dibandingkan pada tahun 2018. Sehingga dapat diketahui bahwa Implementasi Manajemen Risiko Pembiayaan Murabahah tersebut tidak berjalan secara maksimal.

Pelaksanaan Manajemen Risiko Pembiayaan berdasarkan Perspektif Hukum Ekonomi Syariah pada PT. BPRS Baiturrahman bahwa dalam praktiknya telah dilakukan upaya yang serius dari manajemen PT. BPRS Baiturrahman untuk menjalankan kegiatan usahanya sesuai dengan prinsip-prinsip syariah yang mengacu kepada POJK dan Peraturan Perusahaan serta Fatwa DSN MUI terkait Pelaksanaan Produk Perbankan. Dalam aktifitas operasional diawasi secara aktif oleh Dewan Pengawas Syariah. 
Mukhlis

\section{Daftar Pustaka}

Ascarya. (2006). Akad dan Produk Bank Syariah. Jakarta: Raja Grafindo Persada.

Bhagat, S., \& Bolton, B. (2019). Corporate governance and firm performance: The sequel. Journal of Corporate Finance, 58, 142-168. https://doi.org/10.1016/j.jcorpfin.2019.04.006

Dedi Putra dan Nur Istiqomah. (2020). CORPORATE GOVERNANCE DAN KARATERISTIK PERUSAHAAN TERHADAP MANAJEMEN RESIKO PADA PERUSAHAAN KOMPAS 100. Jurnal Ilmiah Akuntansi dan Finansial Indonesia, 3(2), 37-48. https://doi.org/10.31629/jiafi.v3i2.2207

Jiang, F., \& Kim, K. A. (2020). Corporate Governance in China: A Survey*. Review of Finance, 24(4), 733-772. https://doi.org/10.1093/rof/rfaa012

Karim, A. A. (2005). Bank Islam, Analisis Figh dan Keuangan. Jakarta: Raja Grafindo Persada.

Kasmir. (2004). Manajemen Perbankan. Jakarta: Raja Grafindo Persada.

Kovermann, J., \& Velte, P. (2019). The impact of corporate governance on corporate tax avoidance-A literature review. Journal of International Accounting, Auditing and Taxation, 36, 100270. https://doi.org/10.1016/j.intaccaudtax.2019.100270

Muhammad. (2002). Manajemen Bank Syariah. Yogyakarta: Unit Penerbit dan Percetakan.

Muhammad. (2014). Manajemen Dana Bank Syari'ah. Jakarta: Rajawali Pers.

Nazir, M. (2002). Metode Penelitian. Jakarta: Ghalia Indonesia.

Sudarwan Danim. (2002). Menjadi Peneliti Kualitatif. Bandung: Pustaka Setia.

Sugiyono. (2007). Metode Penelitian Kuantitatif Kualitatif. Bandung: Alfabeta.

Suparmin, A. (2019). MANAJEMEN RESIKO DALAM PERSPEKTIF ISLAM. ElArbah: Jurnal Ekonomi, Bisnis Dan Perbankan Syariah, 2(02), 27-47. https://doi.org/10.34005/elarbah.v2i02.551

Tampubolon, R. (2014). Risk management : Qualitative Approach Applied to Commercial Banks. Jakarta: Elex Media Komputindo.

Veithzal, R., \& Ismal. (2013). Islamic Risk management for Islamic Bank. Jakarta: Gramedia Pustaka Utama. 